\title{
The impact of the lockdown by COVID-19 on Temporomandibular Disorder related pain intensity, distress and post-traumatic stress disorder - A case-control study
}

\author{
O impacto do lockdown pela COVID-19 na intensidade dolorosa relacionada à Disfunção
}

Temporomandibular, angústia e transtorno do estresse pós-traumático - Um estudo de casocontrole

El impacto del lockdown de COVID-19 en la intensidad del dolor relacionado con el Trastorno Temporomandibular, la angustia y el trastorno de estrés pós-traumático - Un estudio de casos y controle

Timóteo Sousa Lopes ORCID: https://orcid.org/0000-0003-2574-5861 Federal University of Ceará, Brazil E-mail: timoteoslopes@yahoo.com.br

Paulo Goberlânio de Barros Silva ORCID: https://orcid.org/0000-0002-1513-9027 Federal University of Ceará, Brazil

E-mail: paulo_goberlanio@yahoo.com.br Mirna Marques Bezerra ORCID: https://orcid.org/0000-0003-2146-4456 Federal University of Ceará, Brazil

E-mail: mirna@ufc.br

Lívia Maria Sales Pinto Fiamengui

ORCID: https://orcid.org/0000-0002-2746-2219 Federal University of Ceará, Brazil E-mail: livia_holanda_@hotmail.com

Eulália Mendes de Oliveira ORCID: https://orcid.org/0000-0002-8631-6414 Federal University of Ceará, Brazil E-mail: eulaliamoliveira@alu.ufc.br

Karuza Maria Alves Pereira ORCID: https://orcid.org/0000-0002-2880-6466 Federal University of Ceará, Brazil E-mail: karuzaalves@ufc.br

Hellíada Vasconcelos Chaves ORCID: https://orcid.org/0000-0002-7718-9900 Federal University of Ceará, Brazil E-mail: helliadachaves@ufc.br

\begin{abstract}
The events related to the COVID-19 pandemic are having a strong impact on public mental health. However, there are few studies focusing on these aspects in patients with temporomandibular disorders (TMD). The aim of this study was to evaluate the painful intensity, distress and symptoms of post-traumatic stress disorder (PTSD) in a population with and without TMD during the COVID-19 pandemic. This case-control study evaluated electronic questionnaires from 197 participants (105 with TMD and 92 controls), that were carried out during and after the first lockdown due to COVID-19 pandemic. To assess the presence of possible TMD, painful intensity, distress, and PTSD symptoms the respective questionnaires were used: TMD Pain Screener, Numeric Rating Scale, Patient Health Questionnaire - 4 and PTSD Checklist - Civilian Version. TMD participants showed higher levels of distress during $(\mathrm{p}=0.027)$ and after $(\mathrm{p}$ $<0.001)$ the lockdown compared to the control group. The TMD group also reported increased levels of distress in the post-lockdown period in relation to the period during the lockdown $(\mathrm{p}=0.002)$, although the same intensity of pain was observed at both evaluated periods. Furthermore, participants with TMD were $3.91 \times$ more likely to be female (CI $95 \%=1.88-8.13)$ and $3.82 \times$ more likely to show PTSD symptoms $($ CI95\% $=1.61-9.08)$ after the lockdown. These data suggest that a pre-existing painful condition can lead to increased distress and symptoms of PTSD as a result of stressful situations, such as the COVID-19 pandemic lockdown.
\end{abstract}

Keywords: COVID-19; Social isolation; Mental health; Post-traumatic stress disorder; Temporomandibular joint disorders. 


\begin{abstract}
Resumo
Eventos relacionados com a pandemia da COVID-19 possuem forte impacto na saúde mental pública. Entretanto, existem poucos estudos com foco nesses aspectos em pacientes com disfunção temporomandibular (DTM). O objetivo deste estudo foi avaliar a intensidade dolorosa, angústia e sintomas do transtorno do estresse pós-traumático (TEPT) em uma população com e sem DTM durante a pandemia de COVID-19. Este estudo de caso-controle avaliou questionários eletrônicos de 197 participantes (105 com DTM e 92 controles), que foram realizados durante e após o primeiro lockdown da pandemia de COVID-19. Para avaliar a presença de possíveis sintomas de DTM, intensidade dolorosa, angústia e TEPT foram utilizados os respectivos questionários: TMD Pain Screener, Numeric Rating Scale, Patient Health Questionnaire - 4 e PTSD Checklist - Civilian Version. Os participantes com DTM apresentaram níveis mais elevados de angústia durante $(\mathrm{p}=0,027)$ e após $(\mathrm{p}<0,001)$ o lockdown em comparação ao grupo controle. O grupo DTM também relatou níveis aumentados de angústia no período pós-lockdown em relação ao período durante o lockdown $(\mathrm{p}=0,002)$, embora a mesma intensidade de dor tenha sido observada nos dois períodos avaliados. Além disso, os participantes com DTM foram 3,91 $\times$ mais propensos a ser do sexo feminino (IC 95\% $=$ 1,88-8,13) e 3,82 × mais propensos a apresentar sintomas de TEPT (IC 95\% = 1,61-9,08) após o lockdown. Esses dados sugerem que uma condição dolorosa pré-existente pode levar ao aumento da angústia e dos sintomas de TEPT como resultado de situações estressantes, como o lockdown pela COVID-19.
\end{abstract}

Palavras-chave: COVID-19; Isolamento social; Saúde mental; Transtornos de estresse pós-traumáticos; Síndrome da disfunção da articulação temporomandibular.

\title{
Resumen
}

Hay pocos estudios que analicen los impactos psicológicos de la pandemia de COVID-19 en pacientes con trastornos temporomandibulares (TTD). El objetivo de este estudio fue evaluar la intensidad del dolor, la angustia y los síntomas del trastorno de estrés postraumático (TEPT) en una población con y sin TTM durante la pandemia de COVID-19. Este estudio de casos y controles evaluó cuestionarios de 197 participantes (105 con TMD y 92 controles), que se llevaron a cabo durante y después del primer lockdown por la pandemia de COVID-19. Para evaluar la presencia de posibles síntomas de TMD, intensidad del dolor, angustia y TEPT, se utilizaron los siguientes cuestionarios: TMD Pain Screener, Numeric Rating Scale, Patient Health Questionnaire - 4 y PTSD Checklist - Civilian Version. Los participantes con TTM mostraron niveles más altos de angustia durante $(p=0,027)$ y después $(p<0,001)$ del lockdown en comparación con el grupo de control. El grupo TTM también reportó mayores niveles de angustia en el período posterior al lockdown en comparación con el período durante el lockdown $(\mathrm{p}=0,002)$, aunque se observó la misma intensidad del dolor en ambos períodos evaluados. Además, los participantes con TTM tenían 3,91 × más probabilidades de ser mujeres $(95 \%$ IC $=1,88-8,13)$ y 3,82 $\times$ más probabilidades de tener síntomas de TEPT $(95 \%$ IC $=1,61-9,08)$ después del confinamiento. Estos datos sugieren que una afección dolorosa preexistente puede provocar una mayor angustia y síntomas de TEPT como resultado de situaciones estresantes como el lockdown.

Palabras clave: COVID-19; Aislamiento social; Salud mental; Trastornos por estrés postraumático; Síndrome de la disfunción de articulación temporomandibular.

\section{Introduction}

The new coronavirus disease (COVID-19) caused by the pathogen SARS-CoV-2 was declared by the World Health Organization (WHO) in March 2020 as a global pandemic, thereby becoming a public health emergency of international interest. With the establishment of public policies of social-distancing, countless people around the world have been in social confinement for weeks or even months (Ahmad et al., 2020; Brooks et al., 2020; Ge et al., 2020).

At the present moment, there are many uncertainties concerning the origin, nature, evolution, and severity of COVID19, as well as uncertainties about the ability of governments to prevent the spread of infection, treatment capacity of health systems and their possibility of collapse and the production, acquisition and distribution of vaccines, the sum of these factors creates an environment of fear, anxiety and depression that interferes with basic daily activities of individuals (Almeida-Leite et al., 2020; McIntyre et al., 2021; Mertens et al., 2020). Moreover, the lockdowns imposed by government officials as an attempt to contain the spread of the virus directly impair social interactions, rendering the confined individuals more prone to developing psychosocial changes (Mackolil \& Mackolil, 2020). This series of events has contributed to the development of a large number of studies and reviews on the effects of the COVID-19 pandemic on psychosocial issues of the affected populations (Cénat et al., 2020; Hossain et al., 2020; Salari et al., 2020; Vindegaard \& Eriksen Benros, 2020; Xiong et al., 2020a).

Despite the already established relationship between psychosocial factors, such as anxiety and depression, and 
Temporomandibular Disorders (TMDs) (Afari et al., 2014; De La Torre Canales et al., 2018; Nazeri et al., 2018), there is a paucity of studies investigating how the COVID-19 pandemic and its possible psychosocial impacts could affect manifestations of orofacial pain and TMDs (Asquini et al., 2021; Emodi-Perlman et al., 2020; Gaş et al., 2021; Medeiros et al., 2020; Saccomanno et al., 2020; Vrbanović et al., 2020; Wu et al., 2021). These studies have an important temporal limitation, due to their cross-sectional design (Emodi-Perlman et al., 2020; Gaş et al., 2021; Medeiros et al., 2020; Saccomanno et al., 2020; Vrbanović et al., 2020; Wu et al., 2021), except for the recent longitudinal cohort study by Asquini, et al. (2021) (Asquini et al., 2021). Therefore, the aim of our investigation was to evaluate the sociodemographic profile, presence of possible painful TMD, painful intensity, rates of distress (anxiety and depression), and symptoms of posttraumatic stress disorder (PTSD) of a Brazilian population with and without painful TMD during and after the COVID-19 pandemic lockdown. To the best of our knowledge, this is the first longitudinal case control study in a Brazilian population comparatively evaluating the lockdown and post-lockdown periods in participants with TMD.

\section{Methodology}

\subsection{Study Design}

This case-control study was guided by the Strengthening the Reporting of Observational Studies in Epidemiology (STROBE) checklist, an initiative that aims to strengthen and guide the reporting of observational studies (Malta et al., 2010), and was also carried out following the guidelines of Resolution 466/12 of the Brazilian National Health Council and it was approved by the Research Ethics Committee of the State University of Vale do Acaraú (protocol number: 4.348.365).

\subsection{Setting}

This study was based on the analysis of electronic questionnaires applied during and after the first COVID-19 lockdown imposed by state and municipal decrees in the state of Ceará - Brazil. The first series of questionnaires (during lockdown - T1) was carried out between May 22, 2020, and May 31, 2020, to assess the effect of the lockdown after its longest confinement period. The second series of questionnaires (after lockdown - T2) carried out between October 25, 2020, and November 23, 2020.

\subsection{Participants}

The sample comprised individuals of both sexes - aged between $\geq 18$ and 70 years - previously attended and registered $(2016,2017,2018,2019)$ at the outpatient clinics of the Dentistry Course of the Federal University of Ceará - Campus Sobral Brazil. All volunteers were evaluated using the questionnaire to assess symptoms of painful TMD - TMD Pain Screener and divided into two groups: TMD Group - individuals with a possible TMD; Control group - individuals without TMD. Those who did not have access to the internet to fill the electronic questionnaires, as well as those who answered the questionnaires incompletely.

\subsection{Variables and Data Sources}

Data collection was carried out using the digital platform Google Forms, which was used for the formulation and dissemination of the electronic questionnaires. It is also noteworthy that the questionnaires were self-administered, being completed on mobile devices or personal computers of each participant to guarantee privacy, with no time limit, and to avoid any intentionality bias caused by the researchers.

The variables that were collected for the present study included sociodemographic data: age, sex, marital status, living with children, city and area of residence and educational level. 
During T1, participants were assessed for the presence or absence of "possible painful TMD" using the TMD Pain Screener questionnaire (Ohrbach \& Knibbe, 2016), which is one of the two instruments of the Axis I of the the Diagnostic Criteria for Temporomandibular Disorders (DC/TMD) (Ohrbach, 2016). Participants' distress levels were also evaluated at T1 and T2 through the Four-Item Patient Health Questionnaire - 4 - Distress (Depression and Anxiety) - (PHQ-4) from the Axis II of the DC/TMD (Ohrbach, 2016). This instrument classifies participants as no distress, mild, moderate or severe distress (Ohrbach \& Knibbe, 2016).

The presence of PTSD symptoms was evaluated and described as positive or negative according to the Post-Traumatic Stress Disorder Checklist - Civilian Version (PCL-C) (Bringhenti et al., 2010) questionnaire applied during T2. The intensity of orofacial painful symptoms was assessed in T1 and T2 through the numeric rating scale (NRS) (Dworkin et al., 2005) for pain, which is a simple and valid method for measuring pain intensity, being widely used in clinical settings and researches. The NRS was used to measure the facial pain intensity of each participant on a scale of 0 to 10 , "at the time of the questionnaire" and "in the last 30 days, on average", with 0 meaning 'no pain' and 10 meaning 'pain as bad as you can imagine' (Dworkin et al., 2005).

\subsection{Sample size}

The sample unit adopted in this study was the patient. The sample calculation was based on a study by Vrbanović, et al. (2020) that analyzed TMD patients during the COVID-19 pandemic in Croatia, demonstrating that $21.4 \%$ of the 81 participants developed parafunctional oral habits immediately after the lockdown. It was estimated that a minimum total of 157 patients within a population of 350 patients treated at the Dentistry Course at the Federal University of Ceará - Campus Sobral in the last 4 years was necessary to obtain a sample with $80 \%$ power and $95 \%$ confidence for the alternative hypothesis of this study to be accepted (https://www.openepi.com/SampleSize/SSMean.htm). Considering a 10\% loss of the sample throughout the study, a total of 173 patients was estimated as necessary. (Sample size $n=[N p(1-p)] /[(d 2 / Z 21-\alpha / 2 *(N-1)+p *(1-p))$; in which $\mathrm{N}=350 ; \mathrm{p}=24.4 \%+/-5 ; \alpha=5 \%$ ).

\subsection{Variables and statistical methods}

All data were statistically analysed by software Statistical Packcage for the Social Sciences (SPSS) 20.0 for Windows adopting a $95 \%$ confidence. The data obtained from the NRS were expressed as a mean and standard deviation and analyzed between times of evaluation by Wilcoxon test. The other variables were assessed dichotomously, being presented in the form of absolute frequency and percentage. Age was categorized based on the median and, along with the other categorical variables, it was associated with the case and control groups using Fisher's exact or Pearson's chi-square tests. Variables with $\mathrm{p}$ $<0.200$ (Forward stepwise model) were submitted to multinomial logistic regression analyses. Adjusted odds ratio and its $95 \%$ confidence interval were calculated to significant variables.

\section{Results}

\subsection{Participants}

After analyzing the inclusion and exclusion criteria the questionnaires were sent to 350 patients and answered by 220 participants; however, 6 participants did not fully complete the first sequence of questionnaires, and 17 did not fully complete or did not answer the second sequence of questionnaires. Thus, the sample of the study consisted of 197 participants, of which 105 had a diagnosis of possible TMD, whereas 92 did not meet the criteria for TMD diagnosis. 


\subsection{Descriptive Data}

Most participants were under 30 years old $(\mathrm{n}=122,61.9 \%)$, female $(\mathrm{n}=133,67.5 \%)$, single $(\mathrm{n}=131,66.5 \%)$, had completed high school $(\mathrm{n}=86,43.7 \%)$, no children living together $(\mathrm{n}=142,72.1 \%)$, were from the city of Sobral, $(\mathrm{n}=89$, $45.2)$ and from the urban area $(\mathrm{n}=184,93.4 \%)$. Participants who were aged 30 years or older $(\mathrm{p}=0.018)$, female $(\mathrm{p}<0.001)$ and living together with children $(\mathrm{p}=0.033)$ had a higher prevalence of TMD (Table 1).

Table 1. Influence of the sociodemographic profile on the study population.

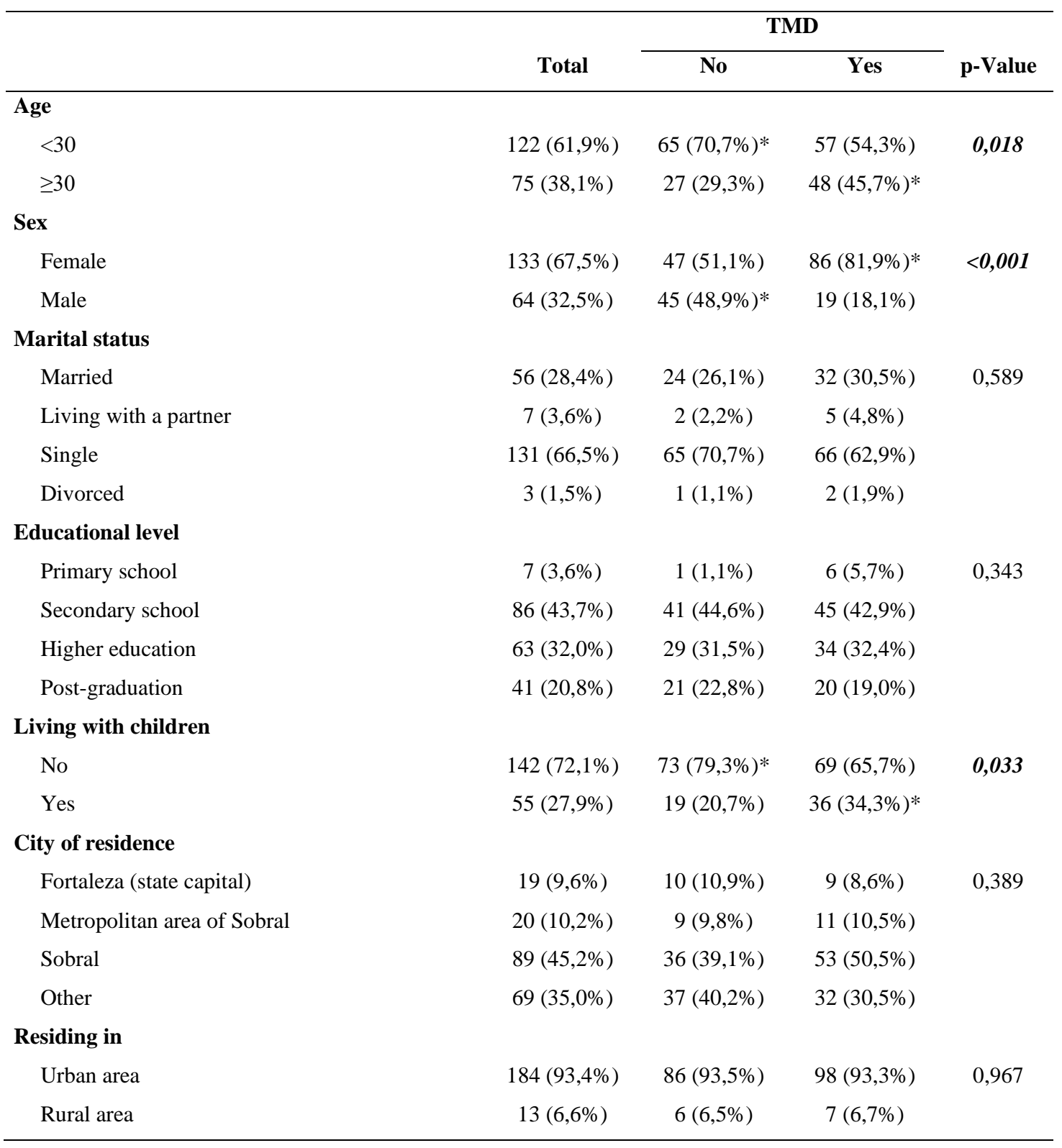

$* \mathrm{p}<0.05$, Fisher's exact test or Pearson's chi-square test (n,\%). Source: Authors.

\section{Main Results and Outcomes}

Most participants had mild distress (depression and anxiety) during $(\mathrm{n}=77,39.1 \%)$ and after $(\mathrm{n}=78,39.6 \%)$ the lockdown, with no significant difference between the two periods $(\mathrm{p}=0.092)$. Fifty seven $(28.9 \%)$ participants showed an increase in distress after the lockdown. Compared to the control group, individuals with TMD had a higher prevalence of 
moderate and severe distress during $(\mathrm{p}=0.027)$ and after $(\mathrm{p}<0.001)$ the lockdown and exhibited an increase in distress levels when comparing the lockdown and post-lockdown periods $(\mathrm{p}=0.002)$ (Table 2).

Table 2. Influence of distress levels (anxiety and depression) and post-traumatic stress disorder (PTSD) on the study population during and after the COVID-19 pandemic lockdown period.

\begin{tabular}{|c|c|c|c|c|}
\hline \multirow{3}{*}{$\begin{array}{l}\text { Distress during lockdown } \\
\end{array}$} & \multirow[b]{2}{*}{ Total } & \multicolumn{2}{|c|}{ TMD } & \multirow[b]{2}{*}{ p-Value } \\
\hline & & \multirow[t]{2}{*}{ No } & \multirow[t]{2}{*}{ Yes } & \\
\hline & & & & \\
\hline No distress & $27(13,7 \%)$ & $18(19,6 \%)^{*}$ & $9(8,6 \%)$ & 0,027 \\
\hline Mild & $77(39,1 \%)$ & $39(42,4 \%)^{*}$ & $38(36,2 \%)$ & \\
\hline Moderate & $68(34,5 \%)$ & $28(30,4 \%)$ & $40(38,1 \%)^{*}$ & \\
\hline Severe & $25(12,7 \%)$ & $7(7,6 \%)$ & $18(17,1 \%)^{*}$ & \\
\hline \multicolumn{5}{|l|}{ Distress after lockdown } \\
\hline No distress & $43(21,8 \%)$ & $28(30,4 \%)^{*}$ & $15(14,3 \%)$ & $<0,001$ \\
\hline Mild & $78(39,6 \%)$ & $44(47,8 \%)^{*}$ & $34(32,4 \%)$ & \\
\hline Moderate & $50(25,4 \%)$ & $15(16,3 \%)$ & $35(33,3 \%)^{*}$ & \\
\hline Severe & $26(13,2 \%)$ & $5(5,4 \%)$ & $21(20,0 \%)^{*}$ & \\
\hline \multicolumn{5}{|l|}{ Distress after lockdown } \\
\hline Reduced/remained the same & $140(71,1 \%)$ & $74(80,4 \%)^{*}$ & $66(62,9 \%)$ & 0,002 \\
\hline Increased & $57(28,9 \%)$ & $18(19,6 \%)$ & $39(37,1 \%)^{*}$ & \\
\hline \multicolumn{5}{|c|}{ Under treatment for anxiety or depression } \\
\hline No & $165(83,8 \%)$ & $81(88,0 \%)$ & $84(80,0 \%)$ & 0,127 \\
\hline Yes & $32(16,2 \%)$ & $11(12,0 \%)$ & $21(20,0 \%)$ & \\
\hline \multicolumn{5}{|l|}{ PTSD symptoms } \\
\hline No & $150(76,1 \%)$ & $82(89,1 \%) *$ & $68(64,8 \%)$ & $<0,001$ \\
\hline Yes & $47(23,9 \%)$ & $10(10,9 \%)$ & $37(35,2 \%)^{*}$ & \\
\hline
\end{tabular}

$* \mathrm{p}<0.05$, Fisher's exact test or Pearson's chi-square test (n,\%). Source: Authors.

Forty seven (23.9\%) participants showed symptoms of PTSD. The prevalence of PTSD symptoms was significantly higher in participants with TMD compared to the control group (p <0.001) (Table 2).

In multivariate analysis, individuals with possible TMD were $3.91 \times(\mathrm{CI} 95 \%=1.88-8.13)$ more likely to be female $(\mathrm{p}$ $=0.001)$ and $3.82 \times(\mathrm{CI} 95 \%=1.61-9.08)$ more likely to have symptoms of PTSD $(\mathrm{p}=0.002)($ Table 3$)$. 
Table 3. Multivariate analysis of factors associated with TMD in participants during and after the COVID-19 pandemic lockdown period.

\begin{tabular}{lcc}
\hline & p-Value & Adjusted OR (CI 95\%) \\
\hline TMD & 0,065 & $2,12(0,95-4,71)$ \\
Age ( $\geq 30)$ & $* \mathbf{0 , 0 0 1}$ & $\mathbf{3 , 9 1}(\mathbf{1 , 8 8 - 8 , \mathbf { 1 3 } )}$ \\
Sex (Female) & 0,586 & $1,27(0,53-3,02)$ \\
Living with children & 0,777 & $1,13(0,49-2,60)$ \\
Distress during lockdown (moderate/severe) & 0,200 & $1,82(0,73-4,57)$ \\
Distress after lockdown (moderate/severe) & 0,167 & $1,86(0,77-4,51)$ \\
Distress (T1 and T2 variation) (increased) & 0,187 & $1,88(0,73-4,84)$ \\
Under treatment for anxiety and depression & $* \mathbf{0 , 0 0 2}$ & $\mathbf{3 , 8 2}(\mathbf{1 , 6 1 - 9 , 0 8 )}$ \\
PTSD symptoms & & \\
\hline
\end{tabular}

$* \mathrm{p}<0.05$, multinomial logistic regression, adjusted $\mathrm{OR}=$ adjusted odds ratio; $95 \% \mathrm{CI}=95 \%$ confidence interval of the adjusted OR. Source: Authors

For TMD participants, the intra-group analysis showed no difference in pain intensity "at the moment" $(\mathrm{p}=0.216)$ (Figure 1) and "in the last 30 days" (p=0.064) (Figure 2) between the two periods.

Figure 1. Influence of the periods during and after the COVID-19 pandemic lockdown on pain intensity (NRS) in participants with possible painful TMD. * p <0.05, Wilcoxon test (mean and 95\% CI).

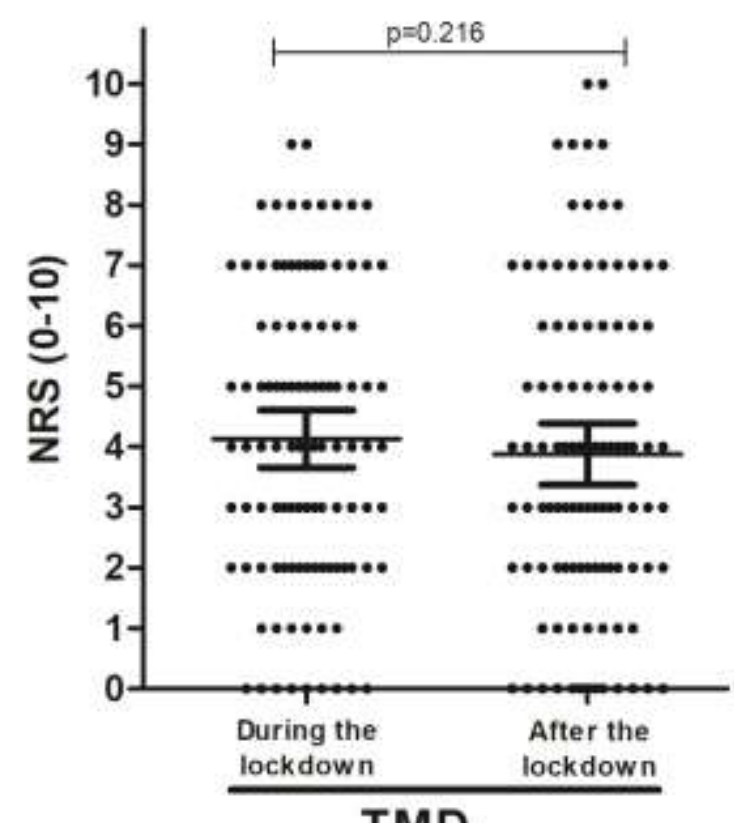

TMD

Source: Authors. 
Figure 2. Influence of the periods during and after the COVID-19 pandemic lockdown on pain intensity (NRS) in the last month (at the moment of the questionnaire) in participants with possible painful TMD. * $\mathrm{p}<0.05$, Wilcoxon test (mean and $95 \% \mathrm{CI})$.

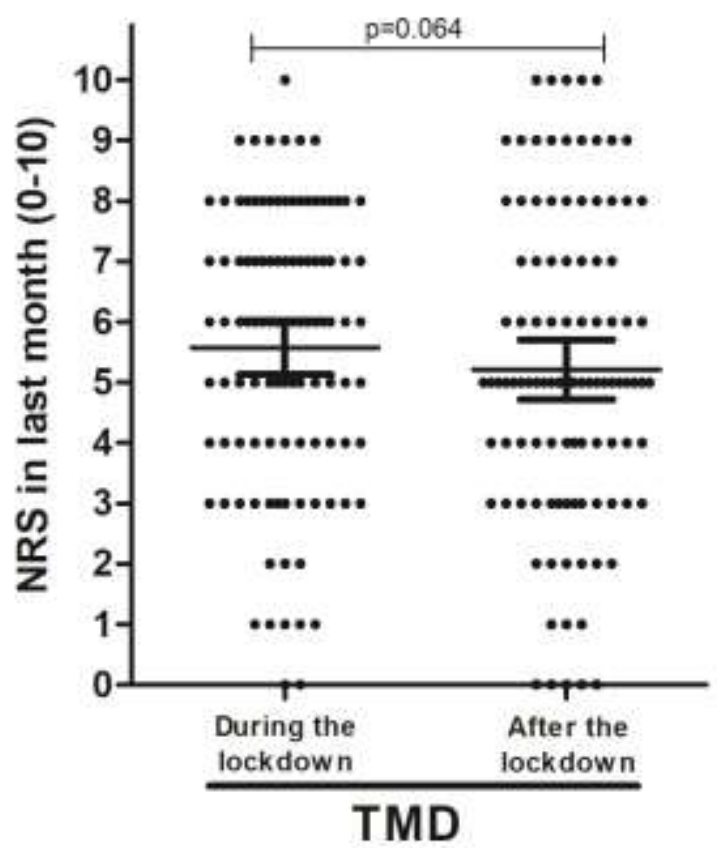

Source: Authors.

\section{Discussion}

The data the current study are extremely relevant since it is the first and so far the only one to perform a longitudinal case-control analysis of patients with possible TMD during and after the lockdown by the pandemic of COVID-19 associating these participants with higher rates of psychological distress (anxiety and depression) and symptoms of PTSD.

In fact, most of our participants experienced some degree of distress (mild, moderate or severe) both during and after the lockdown. This result is in line with recent research on the psychosocial conditions of the general population during the pandemic and the lockdown by COVID-19 (Campos et al., 2020; Daly \& Robinson, 2020; Lei et al., 2020; Passos et al., 2020; Pieh et al., 2020; Salari et al., 2020; Vindegaard \& Eriksen Benros, 2020; Xiong et al., 2020b; Zhang et al., 2020). These studies agree that experiences from the pandemic were responsible for significant effects on the psycho-emotional state of the studied populations and bring the hypothesis that the lockdown and its duration are a risk factor for greater impact on the mental health of the general population with an increase in the prevalence and severity of stress, distress, anxiety and depression.

In addition, it is worth mentioning that our findings corroborate the studies conducted with patients with TMD during the pandemic by COVID-19 (Asquini et al., 2021; Emodi-Perlman et al., 2020; Gaş et al., 2021; Medeiros et al., 2020; Saccomanno et al., 2020; Vrbanović et al., 2020; Wu et al., 2021). These studies suggest that the COVID-19 pandemic was able to increase the prevalence and symptoms of TMD, as well as, similar to our findings, demonstrate important levels of psychosocial changes in patients with TMD during the pandemic.

Despite this, the present study shows no significant difference in the levels of distress (anxiety and depression) between the lockdown and post-lockdown periods in the control population, thus suggesting that the end of the lockdown in this Brazilian population did not present itself as an agent capable of altering this psychosocial condition, as the levels of 
psychological distress remained similar in both periods. This result, however, was different from that found in the group of participants with possible TMD, which showed increased levels of distress in the post-lockdown period.

The non-change in the levels of distress of the participants of the control group and its increase in participants with possible TMD in the post-lockdown period is probably due to the fact that the end of the lockdown does not coincide with the end of the pandemic. Despite this first lockdown was finished, coinciding with the end of the movement restrictions and with the return of non-essential economic activities, the strenuous hygienic behaviors and all the uncertainties and concerns about the infection, also regarding the treatment and the vaccine for COVID-19, as well as with the governments' ability to manage the health and economic setbacks caused by the pandemic still maintained. The non-resolution of this context, its continuity in the medium and long term and the non-prediction of an end continue to create and increase the environment of fear, anxiety and depression caused by the events associated with the pandemic by COVID-19, which would justify these findings (Almeida-Leite et al., 2020; McIntyre et al., 2021; Mertens et al., 2020).

Despite this result, participants with possible TMD had similar levels of pain during and after the lockdown, possibly due to the fact that patients with painful TMD constantly live with high pain intensity indexes (Nguyen et al., 2019; Tjakkes et al., 2010) and therefore they have an already high pain intensity value during the lockdown.

Still on the psychological effects of the pandemic in participants with possible TMD, the relevance of PTSD symptoms should be highlighted, which, in our study, had a significantly higher prevalence in the group of participants with possible TMD when compared to the control group. This finding was so relevant that, in multivariate analysis, participants with possible TMD were 3.82x more likely to have PTSD symptoms compared to the control group.

In fact, the literature describes several recent studies associating PTSD with the experiences of the COVID-19 pandemic in the general population, systematic reviews which sought to assess quarantine and lockdown results in mental health, report that PTSD is among the most prevalent and relevant problems among affected individuals (Cénat et al., 2020; Hossain et al., 2020; Vindegaard \& Eriksen Benros, 2020; Xiong et al., 2020a). It is noteworthy, however, that these studies were performed in populations of patients without TMD. It is also important to note that there is no other study which presents an association of patients with possible TMD with PTSD symptoms caused by the COVID-19 pandemic.

In our study, some sociodemographic factors were found in association with possible TMD during the pandemic. However, it is important to highlight the female sex, since when performing a multivariate analysis, individuals with possible TMD were 3.91 times more likely to be women during the pandemic. The pre- (Maixner et al., 2011; Ostrom et al., 2017; Robinson et al., 2020; Warren \& Fried, 2001) and post- (Emodi-Perlman et al., 2020; Gaş et al., 2021; Saccomanno et al., 2020; Wu et al., 2021)pandemic literature by COVID-19 demonstrates, on its supremacy, that women constitute the majority of patients treated for TMD, who are more likely to develop TMD and have persistent TMD. In this way, the current study adds its findings to the hypothesis raised by the studies mentioned above that women are more exposed to the development of painful TMD symptoms, especially in response to the stress experienced during the pandemic(Emodi-Perlman et al., 2020; Gaş et al., 2021; Maixner et al., 2011; Ostrom et al., 2017; Robinson et al., 2020; Saccomanno et al., 2020; Warren \& Fried, 2001; Wu et al., 2021).

The COVID-19 pandemic and the long lockdown implemented as a measure against the coronavirus transmission restricted full contact with patients; therefore, it was not possible to carry out the physical examination for the establishment of a TMD diagnosis as described in the Axis I of the DC/TMD, limitation also faced by the vast majority of studies dedicated to addressing the relationship between TMDs and the COVID-19 pandemic (Emodi-Perlman et al., 2020; Gaş et al., 2021; Medeiros et al., 2020; Saccomanno et al., 2020; Wu et al., 2021). However, among the possible options for detecting TMD, the TMD Pain Screener was chosen for the diagnosis of possible TMD because it is the most similar to the complete examination protocol out of the two self-report instruments of Axis I of the DC/TMD (Ohrbach, 2016). Other limitation of our study, we 
cite the fact that there are no pre-pandemic data collected, which prevents us from making inferences about whether the beginning of the pandemic altered the prevalence and / or intensity of orofacial pain in participants with possible TMD, limiting us only by the analysis after the end of the lockdown.

\section{Conclusion}

The end of the first lockdown by the COVID-19 pandemic was not an event capable of reducing the levels of distress in participants with possible TMD and controls. On the contrary, TMD patients reported increased levels of distress associated with PTSD symptoms in the post-lockdown period, although the intensity of the pain has been maintained unchanged between the two periods. These data suggests that a pre-existing painful condition may lead to increased distress and PTSD symptoms as a result of stressful situations such as the COVID-19 lockdown.

The continuity of the COVID-19 pandemic in the medium and long term associated with political, economic and health uncertainties generates a climate of fear, stress and distress in people. This climate tends to worsen more and more while the pandemic crisis is not controlled.

With the advancement of the vaccination in the general population and the reduction of social restrictions, new studies should be carried out using the DC/TMD for a more reliable diagnosis of temporomandibular disorders to evaluated the prolonged effects and the psychological impacts of the pandemic in these TMD patients.

\section{Acknowledgments}

This work was supported by Brazilian grants from Conselho Nacional de Desenvolvimento Científico e Tecnológico (CNPq) and Coordenação de Aperfeiçoamento de Pessoal de Nível Superior (CAPES).

\section{References}

Afari, N., Ahumada, S. M., Wright, L. J., Mostoufi, S., Golnari, G., Reis, V., \& Cuneo, J. G. (2014). Psychological trauma and functional somatic syndromes: A systematic review and meta-analysis. Psychosomatic Medicine, 76(1), 2-11. https://doi.org/10.1097/PSY.0000000000000010.

Ahmad, A., Rehman, M. U., \& Alkharfy, K. M. (2020). An alternative approach to minimize the risk of coronavirus (Covid-19) and similar infections. European Review for Medical and Pharmacological Sciences, 24(7), 4030-4034. https://doi.org/10.26355/EURREV_202004_20873.

Almeida-Leite, C. M., Stuginski-Barbosa, J., \& Conti, P. C. R. (2020). How psychosocial and economic impacts of COVID-19 pandemic can interfere on bruxism and temporomandibular disorders? Journal of Applied Oral Science, 28. https://doi.org/10.1590/1678-7757-2020-0263.

Asquini, G., Bianchi, A. E., Borromeo, G., Locatelli, M., \& Falla, D. (2021). The impact of Covid-19-related distress on general health, oral behaviour, psychosocial features, disability and pain intensity in a cohort of Italian patients with temporomandibular disorders. Plos One, 16(2), e0245999. https://doi.org/10.1371/journal.pone.0245999.

Bringhenti, M. E., Luft, C. D. B., \& Oliveira, W. F. de. (2010). Transtorno do estresse pós-traumático em acidentes de trânsito: validação de escala. PsicoUSF, 15(2), 193-203. https://doi.org/10.1590/s1413-82712010000200007.

Brooks, S. K., Webster, R. K., Smith, L. E., Woodland, L., Wessely, S., Greenberg, N., \& Rubin, G. J. (2020). The psychological impact of quarantine and how to reduce it: rapid review of the evidence. The Lancet, 395(10227), 912-920. https://doi.org/10.1016/S0140-6736(20)30460-8.

Campos, J. A. D. B., Martins, B. G., Campos, L. A., Marôco, J., Saadiq, R. A., \& Ruano, R. (2020). Early Psychological Impact of the COVID-19 Pandemic in Brazil: A National Survey. Journal of Clinical Medicine, 9(9), 2976. https://doi.org/10.3390/jcm9092976.

Cénat, J. M., Blais-Rochette, C., Kokou-Kpolou, C. K., Noorishad, P.-G., Mukunzi, J. N., McIntee, S.-E., Dalexis, R. D., Goulet, M.-A., \& Labelle, P. (2020). Prevalence of Symptoms of Depression, Anxiety, Insomnia, Posttraumatic Stress Disorder, and Psychological Distress among Populations Affected by the COVID-19 Pandemic: A Systematic Review and Meta-Analysis. Psychiatry Research, 113599. https://doi.org/10.1016/j.psychres.2020.113599.

Daly, M., \& Robinson, E. (2020). Psychological distress and adaptation to the COVID-19 crisis in the United States. Journal of Psychiatric Research, August, 1-7. https://doi.org/10.1016/j.jpsychires.2020.10.035.

De La Torre Canales, G., Câmara-Souza, M. B., Muñoz Lora, V. R. M., Guarda-Nardini, L., Conti, P. C. R., Rodrigues Garcia, R. M., Del Bel Cury, A. A., \& Manfredini, D. (2018). Prevalence of psychosocial impairment in temporomandibular disorder patients: A systematic review. Journal of Oral Rehabilitation, 45(11), 881-889. https://doi.org/10.1111/joor.12685. 
Dworkin, R. H., Turk, D. C., Farrar, J. T., Haythornthwaite, J. A., Jensen, M. P., Katz, N. P., Kerns, R. D., Stucki, G., Allen, R. R., Bellamy, N., Carr, D. B., Chandler, J., Cowan, P., Dionne, R., Galer, B. S., Hertz, S., Jadad, A. R., Kramer, L. D., Manning, D. C., ... Witter, J. (2005). Core outcome measures for chronic pain clinical trials: IMMPACT recommendations. Pain, 113(1-2), 9-19. https://doi.org/10.1016/j.pain.2004.09.012.

Emodi-Perlman, A., Eli, I., Smardz, J., Uziel, N., Wieckiewicz, G., Gilon, E., Grychowska, N., \& Wieckiewicz, M. (2020). Temporomandibular Disorders and Bruxism Outbreak as a Possible Factor of Orofacial Pain Worsening during the COVID-19 Pandemic - Concomitant Research in Two Countries. Journal of Clinical Medicine, 9(10), 3250. https://doi.org/10.3390/jcm9103250.

Gaş, S., Ekşi Özsoy, H., \& Cesur Aydın, K. (2021). The association between sleep quality, depression, anxiety and stress levels, and temporomandibular joint disorders among Turkish dental students during the COVID-19 pandemic. Cranio : The Journal of Craniomandibular Practice, 00(00), 1-6. https://doi.org/10.1080/08869634.2021.1883364.

Ge, H., Wang, X., Yuan, X., Xiao, G., Wang, C., Deng, T., Yuan, Q., \& Xiao, X. (2020). The epidemiology and clinical information about COVID-19. European Journal of Clinical Microbiology and Infectious Diseases, 39(6), 1011-1019. https://doi.org/10.1007/s10096-020-03874-z.

Hossain, M. M., Sultana, A., \& Purohit, N. (2020). Mental health outcomes of quarantine and isolation for infection prevention: A systematic umbrella review of the global evidence. Epidemiology and Health, e2020038. https://doi.org/10.4178/epih.e2020038.

Lei, L., Huang, X., Zhang, S., Yang, J., Yang, L., \& Xu, M. (2020). Comparison of Prevalence and Associated Factors of Anxiety and Depression among People Affected by versus People Unaffected by Quarantine during the COVID-19 Epidemic in Southwestern China. Medical Science Monitor, 26, 1-12. https://doi.org/10.12659/MSM.924609.

Mackolil, J., \& Mackolil, J. (2020). Addressing psychosocial problems associated with the COVID-19 lockdown. In Asian Journal of Psychiatry (Vol. 51, p. 102156). Elsevier B.V. https://doi.org/10.1016/j.ajp.2020.102156.

Maixner, W., Diatchenko, L., Dubner, R., Fillingim, R. B., Greenspan, J. D., Knott, C., Ohrbach, R., Weir, B., \& Slade, G. D. (2011). Orofacial pain prospective evaluation and risk assessment study - The OPPERA study. Journal of Pain, 12 (11 SUPPL.), T4-T11.e2. https://doi.org/10.1016/j.jpain.2011.08.002.

Malta, M., Cardoso, L. O., Bastos, F. I., Magnanini, M. M. F., \& da Silva, C. M. F. P. (2010). STROBE initiative: guidelines on reporting observational studies. Revista de Saude Publica, 44(3), 559-565. https://doi.org/10.1590/s0034-89102010000300021.

McIntyre, P., Joo, Y. J., Chiu, C., Flanagan, K., \& Macartney, K. (2021). COVID-19 vaccines - Are we there yet? Australian Prescriber, 44(1), 19-25. https://doi.org/10.18773/austprescr.2020.084.

Medeiros, R. A. De, Vieira, D. L., Silva, E. V. F. Da, Rezende, L. V. M. D. L., Santos, R. W. Dos, \& Tabata, L. F. (2020). Prevalence of symptoms of temporomandibular disorders, oral behaviors, anxiety, and depression in Dentistry students during the period of social isolation due to COVID-19. Journal of Applied Oral Science, 28, 1-8. https://doi.org/10.1590/1678-7757-2020-0445.

Mertens, G., Gerritsen, L., Duijndam, S., Salemink, E., \& Engelhard, I. M. (2020). Fear of the coronavirus (COVID-19): Predictors in an online study conducted in March 2020. Journal of Anxiety Disorders, 74, 102258. https://doi.org/10.1016/j.janxdis.2020.102258.

Nazeri, M., Ghahrechahi, H. R., Pourzare, A., Abareghi, F., Samiee-Rad, S., Shabani, M., Arjmand, S., \& Abazarpour, R. (2018). Role of anxiety and depression in association with migraine and myofascial pain temporomandibular disorder. Indian Journal of Dental Research, 29(5), 583-587. https://doi.org/10.4103/0970-9290.244932.

Nguyen, T., Vanichanon, P., Bhalang, K., \& Vongthongsri, S. (2019). Pain Duration and Intensity Are Related to Coexisting Pain and Comorbidities Present in Temporomandibular Disorder Pain Patients. Journal of Oral \& Facial Pain and Headache, 33(2), 205-212. https://doi.org/10.11607/ofph.2088.

Ohrbach, R. (2016). Diagnostic Criteria for Temporomandibular Disorders: Assessment Instruments (Brazilian Portuguese). International Network for Orofacial Pain and Related Disorders Methodology, 1-74.

Ohrbach, R., \& Knibbe, W. (2016). Diagnostic Criteria for Temporomandibular Disorders (DC/TMD) Scoring Manual for Self-Report Instruments. 18.

Ostrom, C., Bair, E., Maixner, W., Dubner, R., Fillingim, R. B., Ohrbach, R., Slade, G. D., \& Greenspan, J. D. (2017). Demographic Predictors of Pain Sensitivity: Results From the OPPERA Study. Journal of Pain, 18(3), 295-307. https://doi.org/10.1016/j.jpain.2016.10.018.

Passos, L., Prazeres, F., Teixeira, A., \& Martins, C. (2020). Impact on mental health due to covid-19 pandemic: Cross-sectional study in portugal and brazil. International Journal of Environmental Research and Public Health, 17(18), 1-13. https://doi.org/10.3390/ijerph17186794.

Pieh, C., Budimir, S., Delgadillo, J., Barkham, M., Fontaine, J. R. J., \& Probst, T. (2020). Mental health during COVID-19 lockdown in the United Kingdom. Psychosomatic Medicine, Publish Ah. https://doi.org/10.1097/psy.0000000000000871.

Robinson, J. L., Johnson, P. M., Kister, K., Yin, M. T., Chen, J., \& Wadhwa, S. (2020). Estrogen signaling impacts temporomandibular joint and periodontal disease pathology. Odontology, 108(2), 153-165. https://doi.org/10.1007/s10266-019-00439-1.

Saccomanno, S., Bernabei, M., Scoppa, F., Pirino, A., Mastrapasqua, R., \& Visco, M. A. (2020). Coronavirus Lockdown as a Major Life Stressor: Does It Affect TMD Symptoms? International Journal of Environmental Research and Public Health, 17(23), 8907. https://doi.org/10.3390/ijerph17238907.

Salari, N., Hosseinian-Far, A., Jalali, R., Vaisi-Raygani, A., Rasoulpoor, S., Mohammadi, M., Rasoulpoor, S., \& Khaledi-Paveh, B. (2020). Prevalence of stress, anxiety, depression among the general population during the COVID-19 pandemic: A systematic review and meta-analysis. Globalization and Health, 16(1), 1-11. https://doi.org/10.1186/s12992-020-00589-w.

Tjakkes, G. H. E., Reinders, J. J., Tenvergert, E. M., \& Stegenga, B. (2010). TMD pain: The effect on health related quality of life and the influence of pain duration. Health and Quality of Life Outcomes, 8, 1-8. https://doi.org/10.1186/1477-7525-8-46. 
Research, Society and Development, v. 11, n. 2, e41811225919, 2022

(CC BY 4.0) | ISSN 2525-3409 | DOI: http://dx.doi.org/10.33448/rsd-v11i2.25919

Vindegaard, N., \& Eriksen Benros, M. (2020). COVID-19 pandemic and mental health consequences: Systematic review of the current evidence. Brain, Behavior, and Immunity, May, 1-12. https://doi.org/10.1016/j.bbi.2020.05.048.

Vrbanović, E., Alajbeg, I. Z., \& Alajbeg, I. (2020). COVID-19 pandemic and Zagreb earthquakes as stressors in patients with temporomandibular disorders. Oral Diseases, $O$ (June), 1-6. https://doi.org/10.1111/odi.13488.

Warren, M. P., \& Fried, J. L. (2001). Temporomandibular disorders and hormones in women. Cells Tissues Organs, 169(3), 187-192. https://doi.org/10.1159/000047881.

Wu, Y., Xiong, X., Fang, X., Sun, W., Yi, Y., Liu, J., \& Wang, J. (2021). Psychological status of TMD patients, orthodontic patients and the general population during the COVID-19 pandemic. Psychology, Health and Medicine, 26(1), 62-74. https://doi.org/10.1080/13548506.2020.1858489.

Xiong, J., Lipsitz, O., Nasri, F., Lui, L. M. W., Gill, H., Phan, L., Chen-Li, D., Iacobucci, M., Ho, R., Majeed, A., \& McIntyre, R. S. (2020a). Impact of COVID-19 pandemic on mental health in the general population: A systematic review. Journal of Affective Disorders, 277, 55-64. https://doi.org/10.1016/j.jad.2020.08.001.

Xiong, J., Lipsitz, O., Nasri, F., Lui, L. M. W., Gill, H., Phan, L., Chen-Li, D., Iacobucci, M., Ho, R., Majeed, A., \& McIntyre, R. S. (2020b). Impact of COVID-19 pandemic on mental health in the general population: A systematic review. Journal of Affective Disorders, 277(August), 55-64. https://doi.org/10.1016/j.jad.2020.08.001.

Zhang, J., Lu, H., Zeng, H., Zhang, S., Du, Q., Jiang, T., \& Du, B. (2020). The differential psychological distress of populations affected by the COVID-19 pandemic. Brain, Behavior, and Immunity, 87(April), 49-50. https://doi.org/10.1016/j.bbi.2020.04.031 